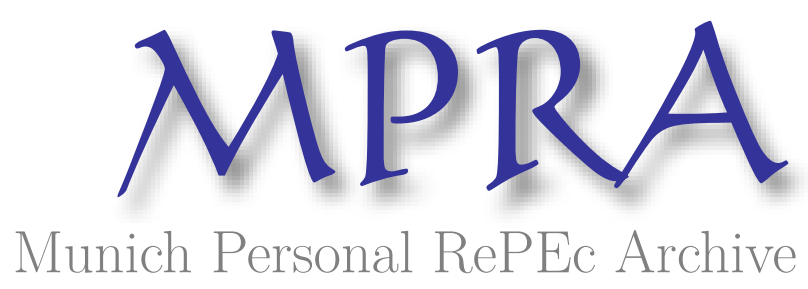

\title{
Islamic norms, the excel formula and home financing models
}

\author{
Hasan, Zubair \\ INCEIF, Kuala Lumpur
}

2012

Online at https://mpra.ub.uni-muenchen.de/47955/

MPRA Paper No. 47955, posted 02 Jul 2013 07:30 UTC 


\title{
Islamic norms, the excel formula and home financing models
}

\author{
Zubair Hasan ${ }^{*}$
}

\begin{abstract}
This paper adds to the series of writings on Islamic home financing presented and published by the author since February 2010. It spells out certain norms Islamic banks must observe in home financing and demonstrates that the conventional model based on an Excel formula does not meet the stated norms. It may well be emphasized that in Islam the question of observing these norms arises before, and not after, the selection of the formula; additional juristic requirements may only follow subsequently. Is it not then strange many Islamic banks are using the formula to determine the periodic instalment payments in their home financing programs? The paper finds, for example, the popular Musharakah-Mutanaqisa Partnership (MMP) Islamic home financing model to be noncompliant with the stated norms. It presents a new model-the Zubair Diminishing Balance Method (ZDBM) - and argues that the alternative is not only fully observant but is superior to the MMP model on some other counts as well.
\end{abstract}

Keywords: Home finance; Excel amortization formula; Compounding; Islamic norms; Justice.

\section{Introduction}

This paper adds to the series of articles on Islamic home financing that the author has presented at conferences or published in academic journals since February 2010 in view of the fast aggravation of the housing problem across countries in view of increasing natural calamities and devastations of war in recent decades. Surprisingly, the central ideas of these writings have received much appreciation and support from the practitioners in the Islamic finance industry or the academia. Most of the writings are listed among the references to the present work. The present paper addresses some of the issues that have attracted much criticism recently. (e.g. Meera, 2012).

In home financing, Islamic banks take care, as they must, to ensure two things: First, they avoid erecting structures that leave any room for riba (interest) to enter the contract they sign with their clients. In this context, recall that compounding is more vociferously condemned in the Qur'an $(2: 275 ; 3: 130)$ than interest. ${ }^{1}$ Otherwise also, to charge "interest on interest" when servicing a loan should be avoided, because it seems unfair to the borrower, almost like kicking a person when he is down (Jon Wittwer, E-mai 2013). Second, the ownership of the property must pass to the customer in the same ratio as the

\footnotetext{
* Zubair Hasan is Professor of Is lamic Economics and Finance at the International Centre for Education in Is lamic Finance (INCEIF), Malaysia. The views expressed in this paper are of the author and need in no way be attributed to INCEIF. The article is to appear in ISRA International Journal of Islamic Finance.

1 Some are of the view that Islam associates compounding to riba alone and not to profit (or rent). The proponents must, however, carry the burden of providing conclusive evidence from Islamic sources of knowledge to prove their point. According to the author, compounding of profit or rent too is not allowed, based on analogical reasoning (See Qur'an 26: 183).
} 
payment compared to the total charge has, at any point in time. Any Islamic home financing model must meet this requirement as well.

Both the stated norms follow from the Qur'an and fall under the Islamic notion of justice (Qur'an, 45: 22; 55: 7-9). Justice has an overriding position among the objectives (maqasid) of Shari'ah. The Qur'an (44: 38-39) states: "Allah has not created the earth and heavens in idle sport but with just ends." Moreover, justice is an inalienable ingredient of the Islamic notion of amanah (trust), the soul of religion. With reference to financial contracts, justice means equality before the law, and the scripture forbids withholding from people that which rightfully belongs to them (Qur'an, 7: 85; 11: 85 and 26: 83).

Both these norms have to be examined for compliance before a home financing contract is validated and signed. The issue here is not the permissibility of the method used for determining a rate of return on capital. The issue is the role the said rate plays in loan amortization and the consequences that follow from the process. One cannot afford to push these matters out of the Shari'ah ambit. The present paper demonstrates that the use of the Excel formula puts into operation a structure that unequivocally violates the stated norms. ${ }^{2}$

In the following section it is explained how compounding is implicit in the Excel formula most Islamic banks use in home financing. Section III thereafter shows how the use of the same formula gives rise to a slower rate of ownership transfer to the customer relative to the stream of payments made. In Section IV the details and structure of the Zubair Diminishing Balance Model (ZDBM) which have received criticisms by, for example, Meera (2012) are presented. Section V then lists the points of superiority of the ZDBM model over the Musharakah-Mutanaqisa Partnership (MMP) model. Finally, Section VI contains some concluding remarks.

\section{Compounding and the excel formula}

In home financing contracts, most of the Islamic banks across the globe use an Excel formula for the determination of the uniform periodic installment payments. This paper investigates if the resultant contract meets the above-stated norms. The formula is as follows:

$$
\mathrm{A}=\mathrm{P}_{0} \cdot \frac{r(1+r)^{n}}{(1+r)^{n}-1}
$$

Here,

A = Installment amount the customer has to pay per time unit to the bank

$\mathrm{P}_{0}=$ Bank's contribution (loan) to the purchase price of the house

\footnotetext{
2 It would be erroneous to argue that the Shari'ah parameters are met once the client has agreed to a rate of return on capital and the process for its amortization. The taking and giving of interest-even more so its compounding - are both disallowed. The bank is not absolved of its obligation to desist from the act even if the client agrees to the compounding, knowingly or unknowingly. For example, a man is not absolved of an adultery charge even if it is proved that the woman had given free consent.
} 
$r=$ the rate of interest payable on outstanding loan per period

$\mathrm{n}=$ Number of time units the payment period is divided; be it a week, a month or a year.

To illustrate, let us assume that a customer buys a house worth $\$ 100,000$. He makes a down payment of $\$ 20,000$ to the seller from his savings and plans to borrow the remaining amount of $\$ 80,000\left(\mathrm{P}_{0}\right)$ from a bank, payable in 10 years in 20 semi-annual instalments. To explore possibilities, he first approaches a conventional bank. He is offered the required terms, the rate of interest per year being $8 \%$. He is to mortgage the house with the bank as security. The bank calculates the instalment amount by inserting the relevant values in the above formula as follows:

$$
\mathrm{A}=80000 \frac{0.04(1+0.04)^{20}}{(1+0.04)^{20}-1}=5887 \text { approximately }
$$

The semi-annual rate of interest used in the formula is $8 / 2=4 \%$ or 0.04 per dollar. Using the value of $\mathrm{A}$ from equation (2) we get the total amount $\left(\mathrm{P}_{\mathrm{n}}\right)$ the bank will receive in 10 years as hereunder:

$$
\mathrm{P}_{\mathrm{n}}=\mathrm{A} * \mathrm{n}=5886.54 * 20=\$ 117,731
$$

The bank's profit (interest income) will be:

$$
\mathrm{P}_{\mathrm{n}}-\mathrm{P}_{0}=117731-80000=\$ 37,731 \text { in } 10 \text { years }
$$

I.e. $\$ 3,773$ a year or $4.72 \%$ on $\$ 80,000$.

Notice that $\mathrm{A}$ is an exponential function of $\mathrm{P}_{0}, \mathrm{r}$ and $\mathrm{n}$. The formula clearly implies compounding of interest income. Interestingly, the fact has explicitly been stated in a 2008 article on Excel published by Microsoft on the internet. Still, how compounding comes into the picture is not clear to many; it needs explanation. We know that the standard compound interest formula is:

$$
P_{n}=P_{0}(1+r)^{n}
$$

The formula capitalizes interest for each of the $\mathrm{n}$ terms to calculate interest for the next or $(\mathrm{n}+1)$ term. The compounding is cumulative if there are no intervening installment payments. Thus, inserting $\mathrm{P}_{0}=\$ 80,000, \mathrm{r}=0.08$ and $\mathrm{n}=10$ in the above formula we get:

$$
\mathrm{P}_{\mathrm{n}}=80000(1+0.08)^{10}=\$ 172,714
$$

We may discount back this amount using the formula $\mathrm{P}_{0}=\mathrm{P}_{\mathrm{n}} /(1+\mathrm{r})^{\mathrm{n}}$ to arrive at the initial loan amount of $\$ 80,000$. 
However, in our illustration semi-annual installments are paid. Therefore, we have to find out the rate $r_{0}$ to verify compounding. Inserting in the formula $P_{n}=P_{0}\left(1+r_{0}\right)^{n}$ the values of $\mathrm{P}_{\mathrm{n}}=\mathrm{A}^{*} \mathrm{n}, \mathrm{P}_{0}$ and $\mathrm{n}$, we may find $\mathrm{r}_{0}$ as hereunder.

$$
5886.54 * 20=80000\left(1+r_{0}\right)^{20}
$$

Dividing through by 20 , we get $5886.54=4000\left(1+r_{0}\right)^{20}$

$$
\begin{aligned}
\ln (5886.54) & =\ln (4000)+20 \ln \left(1+\mathrm{r}_{0}\right) \\
3.7699= & 3.60205+20 \ln \left(1+\mathrm{r}_{0}\right) \\
\ln \left(1+\mathrm{r}_{0}\right)= & (3.7699-3.60205) / 20 \\
= & 0.00839 \\
\left(1+\mathrm{r}_{0}\right) \quad=10^{0.00839} & =1.01951 \\
\mathrm{r}_{0} & =0.01951
\end{aligned}
$$

The compounding rate, $\mathrm{r}_{0}=0.01951$ gives us $1.951 \%$ semi-annually or $3.9 \%$ annually.

Verification:

$$
\begin{aligned}
P_{\mathrm{n}} & =80000(1+0.01951)^{20} \\
& =80000 * 1.47174 \\
& =117,739
\end{aligned}
$$

Return on capital $=117739-80000=37739$

Rate of return per year $4.72 \%$ [same as before]

Using the data we now have, we produce Table 1 below to show how compounding enters into the working of the conventional home financing model. The interest charged is shown in column $E=D_{n}-D_{n-1}$. It can also be found for each time point $n$ by multiplying $(n-1)$ value of $\mathrm{E}$ by $\mathrm{r}_{0}=0.01951$ that equation (5) gives. Thus, for $\mathrm{n}=1$ it would be 80,000* $0.01951=1560.8$ and for $\mathrm{n}=2$, it would be $(80,000+1560.8) * 0.01951=1591.25$, and so on. 
Table 1

The Compound Interest Element in the Conventional Model

\begin{tabular}{|c|c|c|c|c|c|c|c|c|}
\hline $\begin{array}{c}\text { Semi } \\
\text { annual } \\
\text { units }\end{array}$ & $\begin{array}{c}\mathrm{P}_{\mathrm{n}}= \\
\mathrm{P}_{0}\left(1+\mathrm{r}_{0}\right)^{\mathrm{n}}\end{array}$ & $\begin{array}{c}\text { Interest } \\
\text { Charged } \\
\mathrm{E}=\mathrm{D}_{\mathrm{n}}- \\
\mathrm{D}_{\mathrm{n}-1}\end{array}$ & $\begin{array}{c}\text { Compound } \\
\text { Element } 1 \\
\mathrm{E} * \text { ri.e. } \\
\mathrm{E} * 0.04\end{array}$ & $\begin{array}{l}\text { Semi annual } \\
\text { Instalments } \\
\quad \$\end{array}$ & $\begin{array}{c}\text { Outstanding } \\
\text { Balance = } \\
\mathrm{P}_{\mathrm{n}-1}-\mathrm{A}+\mathrm{H}\end{array}$ & $\begin{array}{c}\text { Return on } \\
\text { capital } \\
\mathrm{R} \text { on } \mathrm{C} \\
\mathrm{P}_{\mathrm{n}-1} * 0.04\end{array}$ & $\begin{array}{c}\text { Return } \\
\text { of capital } \\
\mathrm{R} \text { of } \mathrm{C} \\
\mathrm{A}-\mathrm{H}\end{array}$ & $\begin{array}{c}\text { Compoundin } \\
\text { g } \\
\text { Element } 2 \\
=\mathrm{H}^{*} \mathrm{r}= \\
0.04\end{array}$ \\
\hline $\mathrm{n}$ & $\mathrm{D}_{\mathrm{n}}$ & $E$ & $F$ & $\bar{A}$ & $\mathrm{~B}=\mathrm{P}_{\mathrm{n}}$ & $\mathrm{H}$ & $\bar{K}$ & $\bar{M}$ \\
\hline 0 & 80000 & & & & 80000 & & & \\
\hline 1 & 81561 & 1561 & 62 & 5886.54 & 77313 & 3200 & 2687 & 128 \\
\hline 2 & 83152 & 1591 & 64 & 5886.54 & 74520 & 3093 & 2794 & 124 \\
\hline 3 & 84774 & 1622 & 65 & 5886.54 & 71614 & 2981 & 2906 & 119 \\
\hline 4 & 86428 & 1654 & 66 & 5886.54 & 68593 & 2865 & 3022 & 115 \\
\hline 5 & 88115 & 1687 & 67 & 5886.54 & 65450 & 2744 & 3143 & 110 \\
\hline 6 & 89834 & 1719 & 69 & 5886.54 & 62182 & 2618 & 3269 & 105 \\
\hline 7 & 91586 & 1752 & 70 & 5886.54 & 58782 & 2487 & 3399 & 99 \\
\hline 8 & 93373 & 1787 & 71 & 5886.54 & 55247 & 2351 & 3535 & 94 \\
\hline 9 & 95195 & 1822 & 73 & 5886.54 & 51571 & 2210 & 3677 & 88 \\
\hline 10 & 97052 & 1857 & 74 & 5886.54 & 47748 & 2063 & 3824 & 83 \\
\hline 11 & 98946 & 1894 & 76 & 5886.54 & 43771 & 1910 & 3977 & 76 \\
\hline 12 & 100876 & 1930 & 77 & 5886.54 & 39636 & 1751 & 4136 & 70 \\
\hline 13 & 102844 & 1968 & 79 & 5886.54 & 35335 & 1585 & 4301 & 63 \\
\hline 14 & 104851 & 2007 & 80 & 5886.54 & 30862 & 1413 & 4473 & 57 \\
\hline 15 & 106896 & 2045 & 82 & 5886.54 & 26209 & 1234 & 4652 & 49 \\
\hline 16 & 108982 & 2086 & 83 & 5886.54 & 21370 & 1048 & 4838 & 42 \\
\hline 17 & 111108 & 2126 & 85 & 5886.54 & 16338 & 855 & 5032 & 34 \\
\hline 18 & 113280 & 2172 & 87 & 5886.54 & 11105 & 654 & 5233 & 26 \\
\hline 19 & 115486 & 2206 & 88 & 5886.54 & 5662 & 444 & 5442 & 18 \\
\hline 20 & 117739 & 2253 & 90 & 5886.54 & 1 & 227 & 5660 & 9 \\
\hline Total & & 37733 & 1510 & 117730.8 & 37733 & & 79998 & 1509 \\
\hline
\end{tabular}

Compounding, then, is precisely the capitalization of interest for charging interest on interest. The following diagram (Figure 1) provides a simple depiction of the compounding process based on columns $\mathrm{A}, \mathrm{B}$ and $\mathrm{H}$ of Table 2. Column $\mathrm{F}$ isolates the compounding element in interest, for $\mathrm{F}=\mathrm{E} * \mathrm{r}$. Notice that column $\mathrm{D}_{\mathrm{n}}$ records cumulative amounts. Thus, the value for $\mathrm{n}=20$ in that column gives us the aggregated amount $(\$ 117,739)$.

\section{Installments, Return on Capital and Return of Capital}


Table 1 above shows that the Microsoft Excel formula for installment determination involves compounding of interest in home financing. Column $D_{n}$ is obtained by using equation (4) for each $\mathrm{n}$ time point. Column $\mathrm{E}$ records the excess in each cell over the preceding cell value in column $\mathrm{D}_{\mathrm{n}}$. The compounding element in the $\mathrm{F}$ column is obtained by multiplying the amount in column $E$ by the semi-annual rate of interest $r=0.04$. Notice that in Table 2 for each $P_{n}$ we have:

$$
P_{n}=P_{n-1}-A+H
$$

Thus, each time we deduct the installment payment (A) from the preceding value $\left(\mathrm{P}_{\mathrm{n}-1}\right)$, but at the same time we add back the return on capital $(\mathrm{H})$ to arrive at the current balance $\left(\mathrm{P}_{\mathrm{n}}\right)$. In other words, we regularly leave the return on capital embedded in the outstanding balance. We know that $\mathrm{H}=\mathrm{P}_{\mathrm{n}-1}$ * r. Putting this value of $\mathrm{H}$ in (7), we get:

$$
P_{n}=P_{n-1}-A+P_{n-1} * r
$$

Simplifying the above equation we get:

$$
P_{n}=P_{n-1}(1+r)^{n}-A
$$

Compounding is so vivid in the formula: interest is charged on interest all along, down the line. ${ }^{3}$ We have once more isolated the compounding as shown in column M. Thus, two demonstrations are presented on compounding and both give identical results-the sum of column $\mathrm{F}$ equals the sum of column $\mathrm{M}$. Compounding yields a return of almost $0.19 \%$ a year on $\$ 80,000$. The impact of compounding on the customer is clear. Table 1 does not provide the details of how the process of repayment goes with the customer, but Table 2 clarifies the process. Interestingly, one may find the return of capital in column $\mathrm{K}$ growing over time on the compounding principle $(1+\mathrm{r})^{\mathrm{n}}$ in conformity with the evidence provided.

The above discussion reinforces the assertion that the Excel formula for installment determination is not free of compounding. ${ }^{4}$ As said earlier, Microsoft has mentioned the fact in its publications.

\section{Ownership transfer}

To reiterate, norms of justice demand that in Islamic home financing the rates of payment and transfer of ownership to the customer must be identical. One in disagreement with the contention must provide evidence from acceptable fiqh sources that the transfer could be at a slower rate in the current MMP structuring. Here, the analogy of bay al-salam or bay-alistisnah that is at times brought in to defend the slower transfer of ownership is perhaps out of place. One need not compare apples with oranges.

\footnotetext{
${ }^{3}$ But in terms of loan and mortgage payments compoundingis referred to as "negative amortization".

${ }^{4}$ In fact, no formula that attempts to combine the return of capital with the return on it in a uniform installment payment, as in Excel, can be shown to be free of compounding.
} 
Under conventional interest financing, the transfer rate is lower throughout than the payment completed. Out of the uniform installment, the process of compounding necessarily allocates more towards the payment of interest than to the return of capital. Thus, the latter amount becomes smaller than the payment rate. Figure 2 provides visual evidence of this crucial fact, which violates the Islamic norm. The figure is based on the data of Table 3.

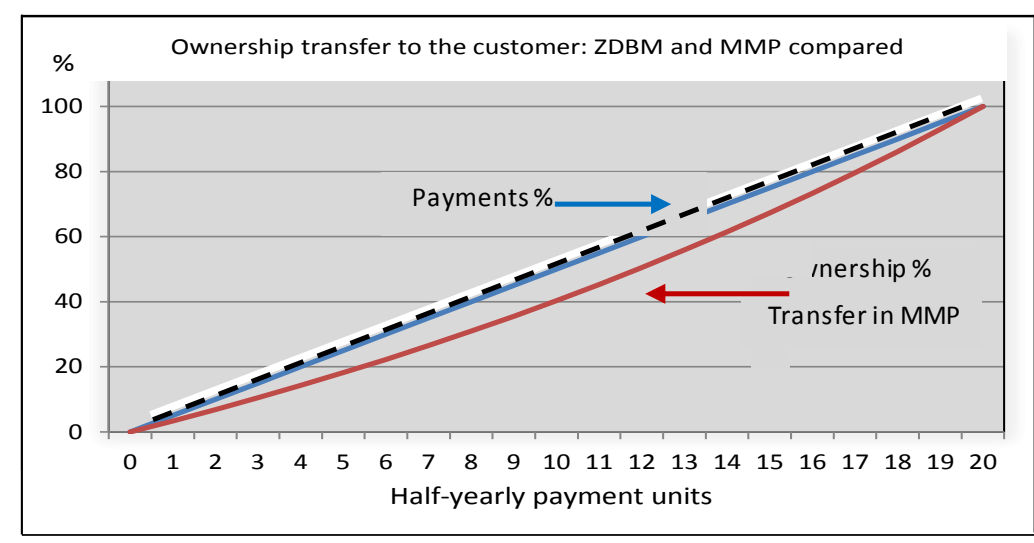

Figure 2: Home financing transfers ownership to the customer at a slower rate than the payment rate in the Conventional \& MMP models but in the $\mathrm{ZDBM}$ it passes at the same rate.

Table 3: Home Ownership Transfer to the Customer in Conventional and Islamic Finance Models

\begin{tabular}{|c|c|c|c|c|c|c|c|c|}
\hline \multirow{4}{*}{$\mathrm{n}$} & \multicolumn{2}{|c|}{ Cumulative Payment L } & \multicolumn{2}{|c|}{$\begin{array}{l}\text { Payment Ratio= } \\
\left(\mathrm{L} / \mathrm{P}_{0}\right) \times 100\end{array}$} & \multicolumn{2}{|c|}{$\begin{array}{c}\text { Balance } \\
\text { Outstanding N }\end{array}$} & \multicolumn{2}{|c|}{$\begin{array}{c}\text { Ownership } \\
\text { Transfer }[(1- \\
\left.\left(\mathrm{N} / \mathrm{P}_{0}\right)\right] \times 100\end{array}$} \\
\hline & CON/MMP & ZDBM & \multirow[b]{2}{*}{$\begin{array}{l}\mathrm{CON} / \\
\mathrm{MMP}\end{array}$} & \multirow[b]{2}{*}{ ZDBM } & \multirow[b]{2}{*}{$\begin{array}{l}\mathrm{CON} / \\
\mathrm{MMP}\end{array}$} & \multirow[b]{2}{*}{ ZDBM } & \multirow[b]{2}{*}{$\begin{array}{l}\text { CON/ } \\
\mathrm{MMP}\end{array}$} & \multirow[b]{2}{*}{ ZDBM } \\
\hline & $\begin{array}{l}\mathrm{R} \text { of } \mathrm{C}+ \\
\mathrm{R} \text { on } \mathrm{C}\end{array}$ & $\mathrm{R}$ of $\mathrm{C}$ & & & & & & \\
\hline & $\mathrm{A}$ & B & $\mathrm{C}$ & $\mathrm{D}$ & $E$ & $\bar{F}$ & $\bar{G}$ & $\mathrm{H}$ \\
\hline 1 & 5886.54 & 4000 & 5 & 5 & 77314 & 76000 & 3.35 & 5 \\
\hline 2 & 11773.08 & 8000 & 10 & 10 & 74520 & 72000 & 6.85 & 10 \\
\hline 3 & 17659.62 & 12000 & 15 & 15 & 71614 & 68000 & 10.48 & 15 \\
\hline 4 & 23546.16 & 16000 & 20 & 20 & 68593 & 64000 & 14.26 & 20 \\
\hline 5 & 29432.70 & 20000 & 25 & 25 & 65450 & 60000 & 18.19 & 25 \\
\hline 6 & 35319.24 & 24000 & 30 & 30 & 62182 & 56000 & 22.27 & 30 \\
\hline 7 & 41205.78 & 28000 & 35 & 35 & 58782 & 52000 & 26.52 & 35 \\
\hline 8 & 47092.32 & 32000 & 40 & 40 & 55247 & 48000 & 30.94 & 40 \\
\hline 9 & 52978.46 & 36000 & 45 & 45 & 51571 & 44000 & 35.54 & 45 \\
\hline 10 & 58865.40 & 40000 & 50 & 50 & 47748 & 40000 & 40.32 & 50 \\
\hline 11 & 64751.94 & 44000 & 55 & 55 & 43771 & 36000 & 45.29 & 55 \\
\hline 12 & 70638.48 & 48000 & 60 & 60 & 39636 & 32000 & 50.46 & 60 \\
\hline 13 & 76525.02 & 52000 & 65 & 65 & 35335 & 28000 & 55.83 & 65 \\
\hline 14 & 82411.56 & 56000 & 70 & 70 & 30862 & 24000 & 61.42 & 70 \\
\hline 15 & 88298.10 & 60000 & 75 & 75 & 26209 & 20000 & 67.24 & 75 \\
\hline 16 & 94184.64 & 64000 & 80 & 80 & 21370 & 16000 & 73.28 & 80 \\
\hline 17 & 100071.18 & 68000 & 85 & 85 & 16338 & 12000 & 79.58 & 85 \\
\hline 18 & 105957.72 & 72000 & 90 & 90 & 11105 & 8000 & 86.12 & 90 \\
\hline 19 & 111844.26 & 76000 & 95 & 95 & 5662 & 4000 & 92.92 & 96 \\
\hline 20 & 117730.80 & 80000 & 100 & 100 & 2 & 0 & 100 & 100 \\
\hline & Total & & & & 117730.8 & & 37733 & \\
\hline
\end{tabular}


On transfer of ownership, columns $\mathrm{C}$ and $\mathrm{G}$ in Table 3 show that it is identically slower in the case of conventional finance and the MMP model. However, in the ZDBM model the ownership transfer to the customer is pro-rata all through-notice columns $\mathrm{D}$ and $\mathrm{H}$ are identical.

\section{ZDBM model: an alternative}

The customer in our illustration subsequently approaches an Islamic bank to find details for obtaining the remaining $\$ 80,000$ payable in 10 years spread over 20 semi-annual installments. The bank, agreeing to meet his requirements, makes the following offer:

The bank shall provide the remaining $\$ 80,000$ to acquire a proprietary share in the house, you acting as our agent. For getting back our investment of $\$ 80,000$ in 20 equal installments spread over 10 years, you will pay $\$ 4,000$ semi-annually. In addition, we shall put a yearly mark-up of $8 \%$ (or $4 \%$ semi-annually) on our ownership share in the house at any point in time, i.e., the mark-up amount will be calculated on the diminishing balance (value) of our share in the property. That would help reduce your liability to the bank over time proportionately. The registration of the house in the court will be in your name, but you will have to sign simultaneously a mortgage deed pledging the property with the bank as security until installments are all cleared.

The client agrees to the terms offered..$^{5}$ The bank provides him a table, given below, detailing his semi-annual installment payments, combining the two components of return of capital and return on capital. This is a simple table, the arrows illustrating how the return on capital is calculated. The de facto average rate of return the client would pay to the bank is $[\$ 33600 / 80000] / 10=4.2 \%$ per annum.

Shorn of the finer legal and regulatory details, the ZDBM structure that the table contains would require three mutually exclusive and independent contracts for consecutive execution.

Table 4: ZDBM in Operation

\begin{tabular}{|c|c|c|c|c|}
\hline $\begin{array}{c}\text { Installment } \\
\# \mathrm{n}\end{array}$ & $\begin{array}{c}\text { Return of } \\
\text { Capital }\end{array}$ & $\begin{array}{c}\text { Outstanding } \\
\text { Balance }\end{array}$ & $\begin{array}{c}\text { Return on } \\
\text { Capital 4\% }\end{array}$ & $\begin{array}{c}\text { Installment } \\
\text { payment }\end{array}$ \\
\hline $\mathrm{A}$ & $\mathrm{B}$ & $\mathrm{C}$ & $\mathrm{D}$ & $\mathrm{E}=\mathrm{B}+\mathrm{D}$ \\
\hline 0 & -- & $\$ 80000$ & -- & -- \\
\hline 1 & $\$ 4000$ & $\$ 76000$ & $-\$ 3200$ & $\$ 7200$ \\
\hline
\end{tabular}

\footnotetext{
${ }^{5}$ We have kept the rate of return in the three cases unchanged at $8 \%$ a year for purposes of comparing the consequences. This indicates that the price can fluctuate. This factor needs to be well researched because, in a murÉbaÍah transaction the sale is completed and thus differs from the rules applicable to a partnership. Classical jurisprudence is clear on this, and I am not convinced that we can make analogical deduction from the sale of share in a partnership for murÉbaÍah. The discussion under the chapter of shufÑah (pre-emption right) in the book of fiqh contains many debates on this aspect of partial sale. Hence the price in murÉbaÍah should be fixed up-front for the validity of the contract of sale. If not, there will be an element of gharar.
} 


\begin{tabular}{|c|c|c|c|c|}
\hline 2 & $\$ 4000$ & $\$ 72000$ & $\$ 3040$ & $\$ 7040$ \\
\hline 3 & $\$ 4000$ & $\$ 68000$ & $\$ 2880$ & $\$ 6880$ \\
\hline 4 & $\$ 4000$ & $\$ 64000$ & $\$ 2720$ & $\$ 6720$ \\
\hline 5 & $\$ 4000$ & $\$ 60000$ & $\$ 2560$ & $\$ 6560$ \\
\hline 6 & $\$ 4000$ & $\$ 56000$ & $\$ 2400$ & $\$ 6400$ \\
\hline 7 & $\$ 4000$ & $\$ 52000$ & $\rightarrow \$ 2240$ & $\$ 6240$ \\
\hline 8 & $\$ 4000$ & $\$ 48000$ & $\$ 2080$ & $\$ 6080$ \\
\hline 9 & $\$ 4000$ & $\$ 44000$ & $\$ 1920$ & $\$ 5920$ \\
\hline 10 & $\$ 4000$ & $\$ 40000$ & $\$ 1760$ & $\$ 5760$ \\
\hline 11 & $\$ 4000$ & $\$ 36000$ & $\$ 1600$ & $\$ 5600$ \\
\hline 12 & $\$ 4000$ & $\$ 32000$ & $\$ 1440$ & $\$ 5440$ \\
\hline 13 & $\$ 4000$ & $\$ 28000$ & $\$ 1280$ & $\$ 5280$ \\
\hline 14 & $\$ 4000$ & $\$ 24000$ & $\$ 1120$ & $\$ 5120$ \\
\hline 15 & $\$ 4000$ & $\$ 20000$ & $\$ 960$ & $\$ 4960$ \\
\hline 16 & $\$ 4000$ & $\$ 16000-$ & $\$ 800$ & $\$ 4800$ \\
\hline 17 & $\$ 4000$ & $\$ 12000$ & $\rightarrow \quad \$ 640$ & $\$ 4640$ \\
\hline 18 & $\$ 4000$ & $\$ 8000$ & $\$ 480$ & $\$ 4480$ \\
\hline 19 & $\$ 4000$ & $\$ 4000$ & $\$ 320$ & $\$ 4320$ \\
\hline 20 & $\$ 4000$ & $\$ 0$ & $\$ 160$ & $\$ 4160$ \\
\hline Total & $\$ 80000$ & $\$ 8400000$ & $\$ 33600$ & $\$ 113600$ \\
\hline
\end{tabular}

1. A sale contract involving the customer, the bank and the seller, giving coownership of the house to the first two in their initial payments ratio of 20:80. The customer will work as their agent, the bank arranging legal authority for him.

2. A second contract whereby the bank sells its share in the property to the customer with an agreed $8 \%$ mark-up over his $\$ 80,000$ investment.

3. A third contract whereby the customer mortgages the house with the bank until all the installments have been paid in full.

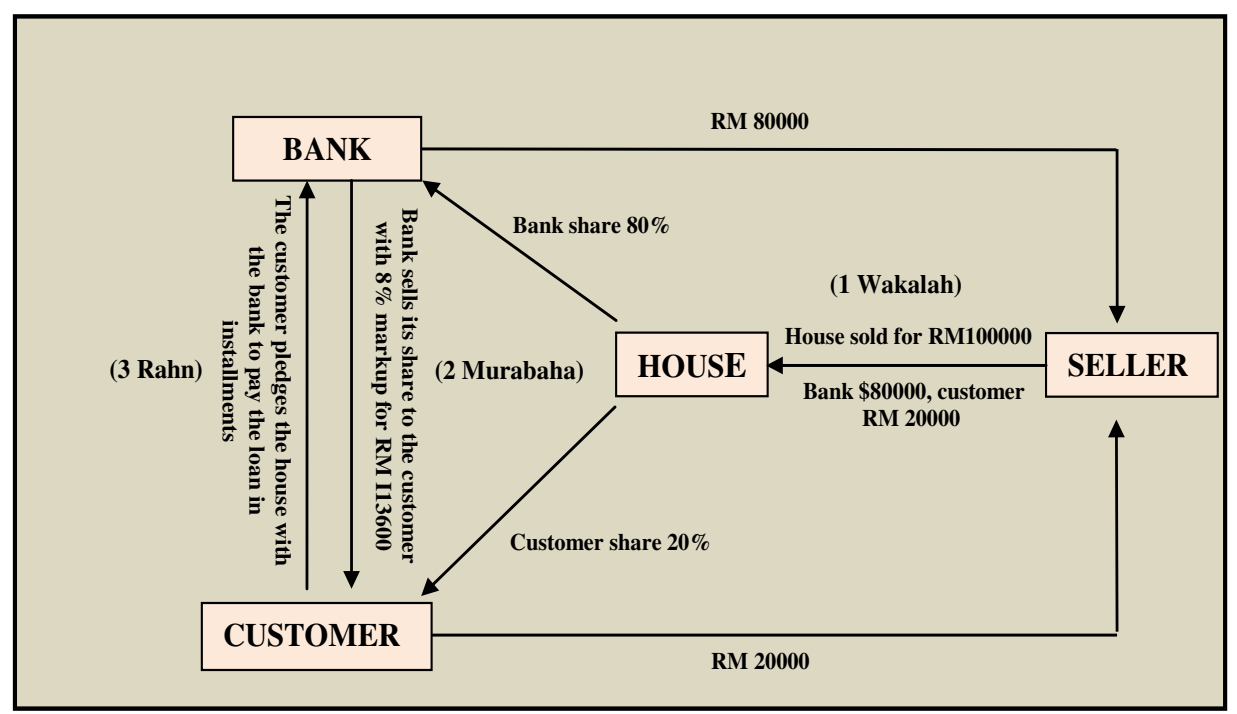

Figure 3: Contractual Structure of the ZDBM 
Figure 3 shows the contractual relationships of the three parties. The seller will be out of the picture after the first contract. Only the client and the bank will stay together for 10 years. In essence, ZDBM is a murabah-mortgage combination. ${ }^{6}$

\section{Comparison of models}

Let us compare the main features of the ZDBM model with the MMP program. We found in Table 4 the results of the two models-conventional and the MMP - to be identical because both models use the same Excel formula for fixing the 10nstalment payment. Leaving aside the issue of compounding of interest, we find some other merits in the ZDBM model. The comparison is facilitated by the following Table.

Table 5: ZDBM vs. MMP - Comparative Data

\begin{tabular}{|c|c|c|c|c|c|c|c|c|}
\hline \multirow{2}{*}{$\mathrm{n}$} & \multicolumn{2}{c|}{$\begin{array}{c}\text { Outstanding } \\
\text { Balance }\end{array}$} & \multicolumn{2}{c|}{$\begin{array}{c}\text { Return of Capital } \\
\text { (R of C) }\end{array}$} & $\begin{array}{c}\text { Return on Capital } \\
\text { (R on C) }\end{array}$ & \multicolumn{2}{c|}{ Installments } \\
\cline { 2 - 9 } & ZDBM & MMP & ZDBM & MMP & ZDBM & MMP & ZDBM & MMP \\
\cline { 2 - 9 } & $\mathbf{A}$ & $\mathbf{B}$ & $\mathbf{C}$ & $\mathbf{D}$ & $\mathbf{E}$ & F & H & K \\
\hline 1 & 80000 & 80000 & 4000 & 2687 & 3200 & 3200 & 7200 & 5887 \\
\hline 2 & 76000 & 77313 & 4000 & 2794 & 3040 & 3093 & 7040 & 5887 \\
\hline 3 & 72000 & 74519 & 4000 & 2906 & 2880 & 2981 & 6880 & 5887 \\
\hline 4 & 68000 & 71614 & 4000 & 3022 & 2720 & 2865 & 6720 & 5887 \\
\hline 5 & 64000 & 68592 & 4000 & 3143 & 2560 & 2744 & 6560 & 5887 \\
\hline 6 & 60000 & 65449 & 4000 & 3269 & 2400 & 2618 & 6400 & 5887 \\
\hline 7 & 56000 & 62180 & 4000 & 3399 & 2240 & 2487 & 6240 & 5887 \\
\hline 8 & 52000 & 58781 & 4000 & 3535 & 2080 & 2351 & 6080 & 5887 \\
\hline 9 & 48000 & 55246 & 4000 & 3677 & 1920 & 2210 & 5920 & 5887 \\
\hline 10 & 44000 & 51569 & 4000 & 3824 & 1780 & 2063 & 5780 & 5887 \\
\hline 11 & 40000 & 47745 & 4000 & 3977 & 1600 & 1910 & 5600 & 5887 \\
\hline 12 & 36000 & 43768 & 4000 & 4136 & 1440 & 1751 & 5440 & 5887 \\
\hline 13 & 32000 & 39633 & 4000 & 4301 & 1280 & 1585 & 5280 & 5887 \\
\hline 14 & 28000 & 35331 & 4000 & 4473 & 1120 & 1413 & $5 I 20$ & 5887 \\
\hline 15 & 24000 & 30858 & 4000 & 4652 & 960 & 1234 & 4960 & 5887 \\
\hline 16 & 20000 & 26206 & 4000 & 4838 & 800 & 1048 & 4800 & 5887 \\
\hline 17 & 16000 & 21368 & 4000 & 5032 & 640 & 855 & 4640 & 5887 \\
\hline 18 & 12000 & 16336 & 4000 & 5233 & 480 & 653 & 4480 & 5887 \\
\hline 19 & 8000 & 11103 & 4000 & 5442 & 320 & 444 & 4320 & 5887 \\
\hline 20 & 4000 & 5660 & 4000 & 5661 & 160 & 226 & 4160 & 5887 \\
\hline Total & $\mathbf{8 4 0 0 0 0}$ & $\mathbf{9 4 3 2 7 0}$ & $\mathbf{8 0 0 0 0}$ & $\mathbf{8 0 0 0 1}$ & $\mathbf{3 3 6 0 0}$ & $\mathbf{3 7 7 3 1}$ & $\mathbf{1 1 3 6 0 0}$ & $\mathbf{1 1 7 7 4 0}$ \\
\hline & & & & & & & & \\
\hline
\end{tabular}

The following facts $^{7}$ are noted based on Table 5:

6 The statement prompted Meera (2012: 7) to conclude "ZDBM would face problems similar to those encountered in BBA financing, particularly when it comes to early settlement; the balance offinancing can even be more than the original financing amount." Problems of this sort could possibly arise if the murabaÍah is initially contracted on the full value of the deferred payment as in BBA. However, in the ZDBM, murabaÍah is segmental; it applies to individual installments, not to them collectively. That makes the ZDBM a sort of innovative proposal. It has no similarity with BBA.

7 The points noted from Table 5 falsify Meera's (2012) claim that the models are similar to one another; they are indeed very different. 
- ZDBM turns out to be cheaper for the customer due to a faster repayment-of-capital plan. For example, in our illustration the customer gains $\$ 4,131$ - the difference between the total of the return-on-capital columns in Table 5.

- Significantly, the customer does not gain at the cost of the banker. Notice that the sum of outstanding balances, which we take as proxy for funding deposits, reduces in the ZDBM proportionate to the reduction in the return-on-capital volume. See the following equation. Figures are from the column totals in the Table.

$$
\begin{array}{lcc}
\text { Models } & \text { Funding Deposits } & \text { Return on Capital } \\
\frac{Z D B M}{M M P}=\frac{840000}{943270}= & \frac{33600}{37731}=0.891
\end{array}
$$

Thus, the margin on funding deposits remains the same in both cases, i.e., 4\%. ZDBM is a win-win model for both the parties: the cost of the house is reduced for the client. Islamic banks get an edge over their conventional rivals while their profit margin remains unchanged.

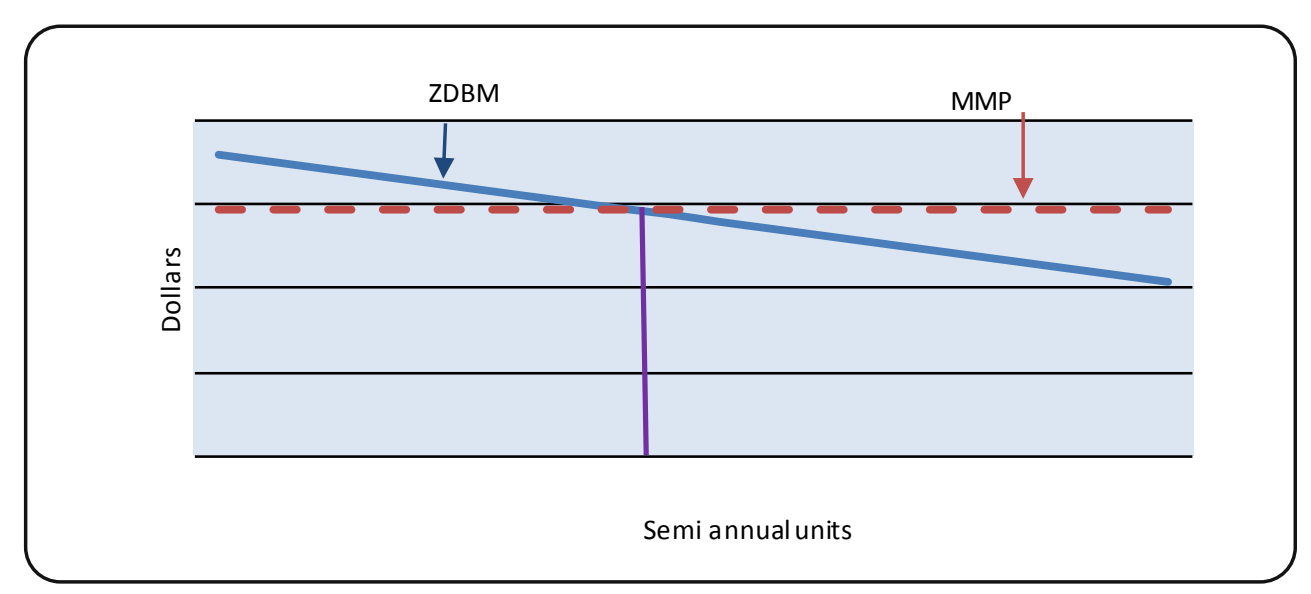

Figure 4: Installment Payments Compared

- The ZDBM model is more efficient; it absorbs fewer resources-funding deposits are smaller. For the same reason, the model must also increase the liquidity levels in the system. The ownership of property passes faster to the customer and we have already shown that it does not harm the bank in any way. The reason is that in the MMP the use of the Excel formula allocates in the beginning a greater proportion of the 11 nstalment payments to return on capital, as shown in Figure 5. 


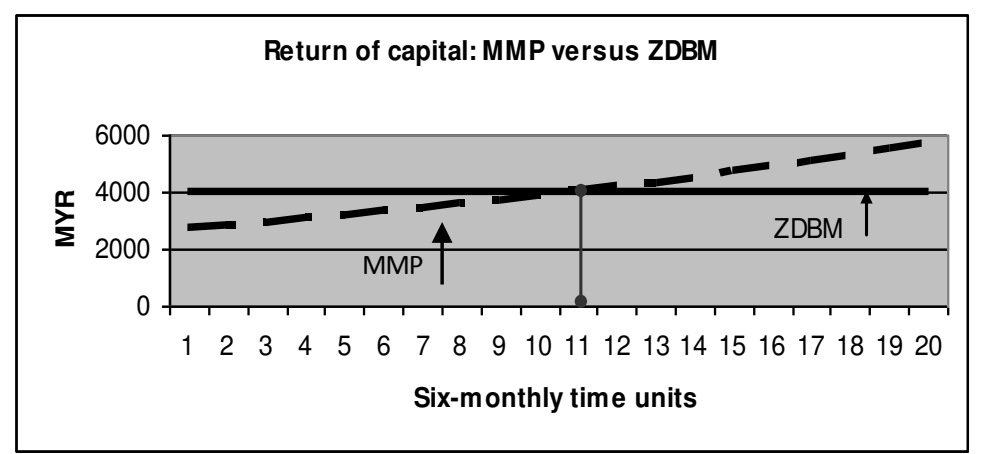

Figure 5: Return of Capital Compared

- Researches show that constant amortization programs, as in the ZDBM model, are more equitable than any other scheme in operation (Chambers et. Al., 2007). In our illustration, halfway down the time scale 50\% ownership passes to the customer as compared to $40 \%$ under the MMP (See, Figure 4). Thus, the margin on funding deposits remains the same in both cases, i.e. $4 \%$. ZDBM is a win-win model for both parties: the cost of the house is reduced for the client while Islamic banks get an edge over their conventional rivals without losing on the profitability front.

- In the case of default, the ZDBM is more equitable to the parties. Suppose in our illustration the default takes place halfway, i.e., after 10 installments have been paid in each case (See Table 5). Under the ZDBM, the buyer's liability reduces proportionately to $50 \%$ while under the MMP he will still have to pay almost $60 \%$ of the debt, i.e., $\$ 47,745$.

- The condition of the customer in default may not be comfortable under the MMP for another reason. A few banks have insisted that not only the balance of capital remaining outstanding but also the return on it for the remaining period must be treated as unpaid liability of the client to meet the banks' commitment to their depositors.

- Home financing usually being of a long-term duration, there may arise-and have arisen in the case of MMP financing-disputes on the revision of rental, the value of the property and the amount of liability remaining unpaid once default takes place. In the ZDBM model matters are much clearer. The return on capital stops at once in case of default. The house will remain under charge for any outstanding balance on capital account alone. The author could not find anything in Islam opposing this arrangement if the parties agree.

- The MMP also requires the creation of three transactions: (i) creation of joint ownership in property; (ii) the financier leases his share in the house to the customer on rent; and (iii) the customer undertakes to purchase different units of the financier's share until the ownership is completely transferred to the former. Taken singly, the jurists regard the three transactions valid if certain conditions are fulfilled. However, it 
is strongly doubted if their combination in a single contract can be allowed (See Usmani, 2010).

- Scholars are divided on the issue of whether the undertaking of the customer to purchase the financier's share in the property would be enforceable in a court of law because it is just promise without counter consideration.

- The shares are not divided in uniform units and the mechanism of determining the fair value of each share is not in place. What is done is to treat the rent portion accruing to the client as both the price and the market value of the share-the client never sees a penny of the rent he earns. He has no option but to agree to this arrangement.

- Some scholars provide implicit support to the MMP structure on the plea that the interest rate serves as a benchmark. The statement is misleading. A benchmark is the reference point to measure the efficacy of the actual value. If it is used in place of the value itself, it no longer remains a benchmark. Sea level is used as the benchmark for heights of existing or future structures from the geographic viewpoint; structures should not be built at that level. The reservation on the point is further strengthened by the recent disclosure of the manipulation of LIBOR by the "too big to fail" Western banks. It is noteworthy that the Islamic Development Bank (IDB) is confronted with the problem of developing a benchmark for Islamic financial institutions.

- Meera (2012) uses the fact of the internal rate of return (IRR) equality in the three models to raise two interesting queries. The first is why the bank for that reason would not be indifferent to a choice between them. Possibly a more relevant question to ask would be why would the bank not be attracted to the ZDBM model to please the customers with lower payments without incurring any additional costs; would it not give Islamic banks a competitive edge over their conventional rivals?

The second question is: from where and how is the $8 \%$ rental rate for the ZDBM model derived? The question looks frivolous in the present context. Using the same rate, whatever be the percentage, is a methodological tool for model comparisons, not an operational reality. In the illustration, La-riba also fixes the rate at $8 \%$ a year. This helped us discover that they too are using the Excel formula. Meera (2009) himself uses $8 \%$ for all models in his critique for comparing results.

- Finally, uniformity of $13 n$ stalment payments is claimed as the main advantage of the MMP program. The customer does not have to readjust his budget every time as the upfront payment is the same. This payment not only remains uniform but is lower than in ZDBM for the early periods thus making it easier for young people to seek house financing even when they are at the lower rungs of the income ladder. But even if one concedes the advantage for a moment, it is questioned whether meeting the Islamic imperatives can be sacrificed for that gain. The criteria for acceding to house financing do not always or entirely dependent, on age. It is well to note that periodic payments in the ZDBM, though not constant, are regular in the sense that they decrease by a 
constant amount. The payments are of course on the higher side to start with, but they become increasingly lower half-way through. Figure 4 above vividly brings out these facts. Which side of the divider one would consider more advantageous cannot be determined a priori; individuals' circumstances would matter. Furthermore, families where both husband and wife work are becoming increasingly common. The trend causes the life-cycle theory to pale into insignificance.

Some have argued that the formulas discussed above are applicable to savings, not to capital amortization. But is not capital is accumulated savings? Banks are intermediaries. They collect savings from scattered entities and convert them into investable funds. Thus the formulas are as much applicable to investments as to savings.

In sum, we have established that the use of Excel formula for instalment payments in home financing violates both the Islamic norms: It is based on the compounding of interest principle and is iniquitous failing to transfer ownership of the house to the buyer commensurate with the periodic payments he makes.

One wishing to refute the above contentions on the academic front has to provide cogent proof that slower payment in the present case would not violate Islamic norms. Classical jurists never faced such eventualities which characterise the modern age. In the author's view the MMP model using the Excel formula violates both the letter and spirit of the Islamic law.

\section{Concluding remarks}

Most Islamic banks have been shifting to the MMP model for home financing. We have shown that Islamic banks using the Excel formula in the MMP models have results identical with those of our conventional model illustration (See also Hasan, 2011a). Our main concern here was to show that there is no juristic ground for the banks to use the Excel formula. The use of the formula palpably violates Islamic requirements. And, to us the debate on the Islamic efficacy of the MMP, or any other model for that matter, starts before selecting the formula for use, not thereafter. We have provided an alternative model for replacing the commonly used MMP. The new model is not only free of blemishes the MMP has, it is cheaper for the customer without any reduction in the margin of profit for the banks as it absorbs proportionately less funds. It is also much better on some related issues like costs, efficiency, liquidity, and equity compared to models Islamic banks presently use for home financing. We feel that the life cycle concerns are trivial in the face of these gains. The fixity of up-front payments cannot condone Shari'ah non-compliance.

Also, the initial higher payments would curb the instinctive urge to go in for houses bigger than the means can probably afford. This was incidentally one of the main causes that led to the sub-prime crisis of 2007 in the US eventually plunging the world into one of the worst ever financial turmoil. 
Finally, once the ZDBM model is recognized for its simplicity, efficiency and freedom from blemishes other models have, Shari'ah scholars may, if need be, tweak the model for Shari'ah compliance. The time is opportune to five ZDBM a trial as housing projects are being promoted en mass in the developed and developing countries alike. In Africa and Asia special attention is being paid to rural housing. The Islamic development Bank has taken initiative to support large projects in Central Asia. National governments are also seized with the housing issues.

\section{References}

American Finance House. LARIBA: Financing Alternative to the Conventional Riba System. Lariba.com Home Financing. Accessed on 24.10.2011.

Chambers, M. S., Garage, C. and Sehlagehauf, D. (2007, September). Mortgage Contracts and Housing Tenure Decisions. Working Paper, Federal Reserve Bank of St. Louis, Research Division, pp. 1-40.

Hasan, Z. (2010). Islamic House Financing: Current Models and a Proposal from Social Perspective. Journal of Islamic Banking \& Finance. Vol. 27, Issue 4.

Hasan, Z. (2011a). Islamic Home Finance in the Social Mirror. ISRA International Journal of Islamic Finance. Vol. 3, Issue 1, June.

Hasan, Z. (2011b). The Diminishing Balance Model for Home Financing. Journal of Islamic Banking \& Finance. Vol. 28, Issue 3.

Hasan, Z. (2011c). Riba in La-Riba Contracts-Where to turn in Islamic Home Financing? MPRA Working Paper \# 35421

Hussain, A. (2010). Islamic Home Financing and Mortgages. Islamic Mortgages.co.uk. Accessed on 1.1.2012.

LARIBA, Knowledge Center. Frequently Asked Questions: In answer to the question: I heard that in your contract you have a term as interest. What does that mean? Accessed on 01.01.2012.

Meera, A. K. (2012). A Critique of Diminishing Balance Method of Islamic Home Financing. ISRA International Journal of Islamic Finance. Vol. 4, Issue 2, December.

Meera, A. K. M. and Razak, D. A. (2009). Home Financing Through the Musharakah Mutanaqisah Contracts: Some Practical Issues. JKAU: Islamic Economics. Vol. 22, No.1.

Microsoft (2011). How to Calculate Compound Interest for an Intra-year Period in Excel. Available at http:/support.microsoft.com/kb/213907

Osmania, N. M. and Abdullah, M. F. (2010). Musharakah Mutanaqisa Home Financing: A Review of Literatures and Practices of Islamic Banks in Malaysia. International Review of Business Research Papers. Vol. 6, No. 213.

Smolo, E. and Hassan, M. K. (2011). The Potentials of Musharakah Mutanaqisa for Islamic Housing Finance. International Journal of Middle Eastern Finance and Management. Vol. 4, No. 3, pp. 237-258.

Usmani, T. (2010). Musharakah and Mudarabah as Modes of Financing. Journal of Islamic Banking \& Finance. Vol. 27, Issue 3.

Wittwer, Jon (2012). Amortization Calculation Formula-Excel. Available at http://www.vertex42.com/Calculators/simple-interest-loan.html 